\title{
Some Clarifications Regarding Literature on Atmospheric Corrosion of Weathering Steels
}

\author{
I. Díaz, H. Cano, B. Chico, D. de la Fuente, and M. Morcillo \\ Department of Surface Engineering, Corrosion, and Durability, National Centre for Metallurgical Research (CENIM/CSIC), \\ Avenida Gregorio del Amo 8, 28040 Madrid, Spain
}

Correspondence should be addressed to I. Díaz, ivan.diaz@cenim.csic.es

Received 19 July 2011; Accepted 20 September 2011

Academic Editor: Alejandro R. Di Sarli

Copyright ( 2012 I. Díaz et al. This is an open access article distributed under the Creative Commons Attribution License, which permits unrestricted use, distribution, and reproduction in any medium, provided the original work is properly cited.

Extensive research work has thrown light on the requisites for a protective rust layer to form on weathering steels (WSs) in the atmosphere, one of the most important is the existence of wet/dry cycling. However, the abundant literature on WS behaviour in different atmospheres can sometimes be confusing and lacks clear criteria regarding certain aspects that are addressed in the present paper. What corrosion models best fit the obtained data? How long does it take for the rust layer to stabilize? What is the morphology and structure of the protective rust layer? What is an acceptable corrosion rate for unpainted WS? What are the guideline environmental conditions, time of wetness (TOW), $\mathrm{SO}_{2}$, and $\mathrm{Cl}^{-}$, for unpainted WS? The paper makes a review of the bibliography on this issue.

\section{Introduction}

Weathering steels (WS), also known as low-alloy steels, are mild steels with a carbon content of less than $0.2 \% \mathrm{wt}$, to which mainly $\mathrm{Cu}, \mathrm{Cr}, \mathrm{Ni}, \mathrm{P}, \mathrm{Si}$, and $\mathrm{Mn}$ are added as alloying elements to a total of no more than $3.5 \%$ wt [1]. The enhanced corrosion resistance of WS is due to the formation of a dense and well-adhering corrosion product layer known as patina. Besides possessing greater mechanical strength and corrosion resistance than mild steel, the patina is also valued for its attractive appearance and self-healing abilities. The main applications for WS include civil structures such as bridges and other load-bearing structures, road installations, electricity posts, utility towers, guide rails, ornamental sculptures, façades, and roofing.

The recent introduction of high-performance steel, a new high-strength WS that does not require painting, has dramatically increased the number of steel bridges being built throughout the world, which has approximately trebled in the last ten years and now accounts for more than $15 \%$ of the market [2]. WS is an attractive material that reduces the life cycle cost of steel structures, which remain in service for long periods of time [3].
Extensive research work has thrown light on the requisites for the protective rust layer to form. It is now well accepted that wet/dry cycling is necessary to form a dense and adherent rust layer, with rainwater washing the steel surface well, accumulated moisture draining easily, and a fast drying action. Surfaces protected from the sun and rain (sheltered) tend to form loose and poorly compacted rust, while surfaces freely exposed to the sun and rain produce more compact and protective rust layers. The structures should be free of interstices, crevices, cavities, and other places where water can collect, as corrosion would progress without the formation of a protective patina. It is also not advisable to use bare weathering steels in indoor atmospheres due to the lack of alternate wetting and drying cycles which are necessary to physically consolidate the rust film, or in marine atmospheres where the protective patina does not form.

However, the abundant literature can be sometimes confusing and lacks clear criteria regarding certain concepts that are addressed in the present paper, namely:

(i) what laws best fit the atmospheric corrosion of WS?

(ii) how long does it take to reach a steady state (stabilization of the rust layer) in which the corrosion rate remains practically constant? 
(iii) what is the morphology and structure of the protective rust layer?

(iv) what is an acceptable corrosion rate for the use of unpainted WS?

(v) what are the guideline environmental conditions (TOW, $\mathrm{SO}_{2}$, and $\mathrm{Cl}^{-}$) for the use of unpainted WS?

Each of these items is reviewed below.

\section{Models Governing the Evolution of Atmospheric Corrosion of Weathering Steel with Exposure Time}

As the use of weathering steels in civil engineering became more common, it became necessary to estimate in-service corrosion penetration.

Corrosion penetration data is usually fitted to a power model involving logarithmic transformation of the exposure time and corrosion penetration. This power function (also called the bilogarithmic law) is widely used to predict the atmospheric corrosion behaviour of metallic materials even after long exposure times, and its accuracy and reliability have been demonstrated by a great number of authors [4-7].

Legault et al. $[5,8]$ noted that atmospheric corrosion of WS in industrial and marine environments may be described by the expression

$$
C=A t^{n}
$$

or its logarithmic transformation:

$$
\ln C=\ln A+n \ln t
$$

where $C$ is the corrosion after time $t$, and $A$ and $n$ are constants.

Pourbaix [6] also stated that the bilogarithmic law is valid for different types of atmospheres and for a number of materials and is helpful in extrapolating results of corrosion up to 20-30 years from four-year test results.

The $n$ value can provide a criterion for gauging longterm atmospheric corrosion susceptibility. It gives a measure of the resistance to transport processes within the corrosion product oxide once it has formed [8]. When $n$ is close to 0.5 , it can result from an ideal diffusion-controlled mechanism when all the corrosion products remain on the metal surface. This situation seems to occur in slightly polluted inland atmospheres. On the other hand, $n$ values of more than 0.5 arise due to acceleration of the diffusion process (e.g., as a result of rust detachment by erosion, dissolution, flaking, cracking, etc.). This situation is typical of marine atmospheres, even those with low-chloride contents. Conversely, $n$ values of less than 0.5 result from a decrease in the diffusion coefficient with time through recrystallisation, agglomeration, compaction, and so forth of the rust layer [9].

In the special case when $n=1$, the mean corrosion rate for one-year exposure is equal to $A$, the intersection of the line on the bilogarithmic plot with the abscissa $t=1$ year. There is no physical sense in $n>1$ as $n=1$ is the limit for unimpeded diffusion (high permeable corrosion products or no layer at all). Values of $n>1$ occur practically as exceptions, due, for instance, to outliers in the mass loss determinations. As a rule, $n<1$. Therefore, $n$ could be used as an indicator for the physicochemical behaviour of the corrosion layer and hence for its interactions with the atmospheric environment. The value of $n$ would thus depend both on the metal concerned, the local atmosphere, maximum exposure time, and the exposure conditions.

On the other hand, the parameter $A$ provides a criterion for gauging short-term atmospheric corrosion susceptibility. It provides a measure of the inherent reactivity of a metal surface as reflected in the tendency for that surface to produce a corrosion product layer in a short-term atmospheric exposure [8].

McCuen et al. [10] proposed to improve the power model setting numerically $A$ and $n$ coefficients with the nonlinear least-squares method directly to the actual values of the variables $C$ and $t$, not the logarithms of the variables, since the logarithmic transformation gives too much weight to the penetration data for shorter exposure. This eliminates the overall bias, and more accurately predicts penetration for longer exposure times. They call numerical power model to this new model which has the same functional form as the bilogarithmic model.

Nevertheless, they saw that WS corrosion penetration data revealed behaviour differences that could not all be explained by the parabolic model and thus preferred a composite model (power-linear model) consisting of a power function for short exposure times, up to 3 to 5 years, followed by a linear function for longer exposure times. This model is similar to that used to develop standard ISO 9224 [11], which envisages two exposure periods with different corrosion kinetics. In the first period, covering the first ten years of exposure, the growth law is parabolic (average corrosion rate, $r_{\mathrm{av}}$ ), while in second period, for times of more than 10 years, the behaviour is linear (steady state corrosion rate, $r_{\text {lin }}$ ).

ISO 9224 [11] offers information on guiding corrosion values for carbon steel and weathering steel (Table 1) in each time period according to the atmospheric corrosivity as defined in ISO 9223 [12]. The guiding corrosion values are based on experience obtained with a large number of exposure sites and service performances.

The question of whether this law provides a better prediction of WS corrosion cannot be fully answered until a greater volume of data is available for analysis, with reference to exposure times of at least 20 years. McCuen and Albrecht compared both models (the power model and the powerlinear model) using atmospheric corrosion data reported for WS in the United States and concluded that the experimental data fitted the power-linear model better than the power model and thus provided more accurate predictions of longterm atmospheric corrosion [13].

Finally, Klinesmith et al. [14] mention that all variation related to environmental conditions appears as error variation in the time-dependent models for models that predict corrosion loss as a function of time only. Further, time-dependent models will yield inaccurate predictions when used to estimate corrosion loss in environments that are different from the environment where the model was 
TABLE 1: Guiding corrosion values for corrosion rates $\left(r_{\mathrm{av}}, r_{\text {lin }}\right)$ of carbon steel and weathering steel in atmospheres of various corrosivity categories.

\begin{tabular}{|c|c|c|c|c|c|}
\hline \multirow{2}{*}{ Metal } & \multicolumn{5}{|c|}{ Average corrosion rate $\left(r_{\mathrm{av}}\right)$ during the first 10 years for the following corrosivity categories (ISO 9223) } \\
\hline & $\mathrm{C} 1$ & $\mathrm{C} 2$ & $\mathrm{C} 3$ & $\mathrm{C} 4$ & $\mathrm{C} 5$ \\
\hline Carbon steel & $r_{\mathrm{av}} \leq 0.5$ & $0.5<r_{\mathrm{av}} \leq 5$ & $5<r_{\mathrm{av}} \leq 12$ & $12<r_{\mathrm{av}} \leq 30$ & $30<r_{\mathrm{av}} \leq 100$ \\
\hline Weathering steel & $r_{\mathrm{av}} \leq 0.1$ & $0.1<r_{\mathrm{av}} \leq 2$ & $2<r_{\mathrm{av}} \leq 8$ & $8<r_{\mathrm{av}} \leq 15$ & $15<r_{\mathrm{av}} \leq 80$ \\
\hline \multirow{2}{*}{ Metal } & \multicolumn{5}{|c|}{ Steady state corrosion rate $\left(r_{\text {lin }}\right)$ for the following corrosivity categories (ISO 9223) } \\
\hline & $\mathrm{C} 1$ & $\mathrm{C} 2$ & $\mathrm{C} 3$ & $\mathrm{C} 4$ & $\mathrm{C} 5$ \\
\hline Carbon steel & $r_{\text {lin }} \leq 0.1$ & $0.1<r_{\text {lin }} \leq 1.5$ & $1.5<r_{\text {lin }} \leq 6$ & $6<r_{\text {lin }} \leq 20$ & $20<r_{\text {lin }} \leq 90$ \\
\hline Weathering steel & $r_{\text {lin }} \leq 0.1$ & $0.1<r_{\text {lin }} \leq 1$ & $1<r_{\text {lin }} \leq 5$ & $5<r_{\text {lin }} \leq 10$ & $10<r_{\text {lin }} \leq 80$ \\
\hline
\end{tabular}

calibrated. To overcome the problem noted, they propose a model that incorporates multiple environmental factors such as TOW, $\mathrm{SO}_{2}, \mathrm{Cl}^{-}$, and temperature $(T)$ :

$$
C=A t^{B}\left(\frac{\mathrm{TOW}}{D}\right)^{E}\left(1+\frac{\mathrm{SO}_{2}}{F}\right)^{G}\left(1+\frac{\mathrm{Cl}}{H}\right)^{I} e^{J\left(T+T_{0}\right)},
$$

where $A, B, D, E, F, G, H, I, J$, and $T_{0}$ are empirical coefficients.

The model was formulated for different metals and the results indicate that it was reliable for use in a broad range of conditions or locations.

In spite of that, recent studies on the long-term atmospheric corrosion of WS continue to use the power function because of its simplicity $[6,15,16]$, although ignoring the linear part will introduce considerable error in thickness estimates for long exposure times.

\section{Rust Layer Stabilisation Time}

Information on this aspect is highly erratic and variable, going from claims that a protective patina can be seen to be forming after as little as 6 weeks exposure in environments with low pollution to reports of stabilisation times of " $a$ few years," one year, 2-3 years, 8 years, and so forth.

The time taken to reach a steady state of atmospheric corrosion will obviously depend on the environmental conditions of the atmosphere where the steel is exposed, and to address this issue it is important to have abundant information on the effect of climatic and atmospheric pollution variables on WS corrosion resistance. However, the fact is that unfortunately there is no solid grounding (supported by ample experimentation) upon which to base relationships between atmospheric exposure and WS corrosion variables.

Despite the scarcity of information, a review has been made of published field data on the atmospheric corrosion of WS in different atmospheres, especially for long exposure times.

Table 2 offers a compendium of data encountered in the literature which may be useful in this respect. One factor of uncertainty is that atmospheres are mostly classified in purely qualitative terms (rural, urban, industrial, or marine), based on a subjective appreciation of pollution factors and omitting the humidity variable. On the other hand, although there is a large amount of data on behaviour in the first years of exposure, there is an ostensible lack of information on exposure times of more than 20 years.

The plotting of corrosion versus exposure time has allowed to estimate the time necessary for stabilisation (steady state) of the rust layer, which would indicate the time necessary for the formation of protective layers (column 6). Indeed, a look at Table 2 allows observing that after very short exposure times (3-5 years) stabilised (protective) rust layers are commonly formed in rural and urban atmospheres. Longer exposure times (5-10 years) are usually required in industrial atmospheres. With regard to marine atmospheres, although little information is available, corrosion rates are seen to be higher, and the time taken to reach the steady state, if it is reached, tends to be longer, in excess of 15 years.

Table 2 also offers important information on aspects such as the effect of the type of atmosphere on WS corrosion, specifically, about the corrosivity category (column 5) as a function of 1st-year corrosion, long-term WS corrosion rates (column 7), and the relationship between carbon steel corrosion and WS corrosion (column 8), aspects on which reported data in the literature are highly variable.

In relation to the influence of the type of atmosphere in the corrosion of weathering steel, as in the case of carbon steel, it can clearly be seen how WS corrosion rises going from a practically pollution-free rural atmosphere (C2) to an urban atmosphere (C2-C3) and from there to industrial and marine atmospheres (C3-C4).

Particular mention should be made of the effect of atmospheric $\mathrm{SO}_{2}$ pollution on WS corrosion, where the existing literature is rather confusing, from those who say that WS is less sensitive to $\mathrm{SO}_{2}$ than carbon steel, especially for long exposure time, to those who believe that "weathering steels need access to $\mathrm{SO}_{2}$ or sulphate-containing aerosols to improve their corrosion resistance," [28] or "it is generally accepted that a low but finite concentration of $\mathrm{SO}_{2}$ in the atmosphere can actually assist the formation of a protective layer on WS." In the first case, Satake and Moroishi [29] report a close relationship between corrosion losses and $\mathrm{SO}_{2}$ contents in the air in the first year of exposure but which disappears in the fifth year of exposure. On the contrary, ISO 9223 [12] notes that "in atmospheres with $\mathrm{SO}_{2}$ pollution a more protective rust layer is formed." The literature also reports that copper in WS can form small amounts of relatively insoluble copper hydroxy sulphates, such as 
TABLE 2: Compendium of bibliographic information on evolution of atmospheric corrosion of conventional WS with time of exposure.

\begin{tabular}{|c|c|c|c|c|c|c|c|}
\hline \multirow[b]{2}{*}{ Reference } & \multirow[b]{2}{*}{ Test site } & \multirow[b]{2}{*}{ Country } & \multirow[b]{2}{*}{ Atmosphere } & \multirow{2}{*}{$\begin{array}{l}\text { Corrosivity } \\
\text { category (ISO } \\
9223)[12]\end{array}$} & \multirow{2}{*}{$\begin{array}{c}\text { Time (years) for } \\
\text { steady-state } \\
\text { condition }\end{array}$} & \multicolumn{2}{|c|}{ At the longest exposure time (years) } \\
\hline & & & & & & $\begin{array}{c}\text { Corrosion rate } \\
(\mu \mathrm{m} / \mathrm{y})\end{array}$ & $\begin{array}{c}R^{*} \\
(\mathrm{CS} / \mathrm{WS}) \\
\end{array}$ \\
\hline$[17]$ & South Bend & USA & Rural & $\mathrm{C} 2$ & $5-10$ & $1.7(15.5 y)$ & $4.6(15.5 y)$ \\
\hline$[18]$ & Sailorsburg & USA & Rural & $\mathrm{C} 2$ & $5-10$ & $3.4(16 y)$ & $3.5(16 y)$ \\
\hline [19] & Potter County & USA & Rural & $\mathrm{C} 2$ & 3 & $2.5(8-16 y)$ & $2.9(8-16 y)$ \\
\hline$[17]$ & State College & USA & Rural & C3 & 3 & $7.3(7 y)$ & $1.9(7 y)$ \\
\hline$[20]$ & Cincinnati & USA & Urban & $\mathrm{C} 2$ & 5 & $4.8(5.3 \mathrm{y})$ & $1.5(5.3 \mathrm{y})$ \\
\hline$[20]$ & Detroit & USA & Urban & $\mathrm{C} 2$ & $5-10$ & $9.2(5.3 \mathrm{y})$ & $1.5(5.3 \mathrm{y})$ \\
\hline$[20]$ & Los Angeles & USA & Urban & $\mathrm{C} 2$ & 5 & $4.4(5.3 \mathrm{y})$ & $1.1(5.3 \mathrm{y})$ \\
\hline$[20]$ & Philadelphia & USA & Urban & $\mathrm{C} 2$ & 5 & $6.3(5.3 y)$ & $1.5(5.3 \mathrm{y})$ \\
\hline$[20]$ & Washington & USA & Urban & $\mathrm{C} 2$ & 5 & $4.9(5.3 \mathrm{y})$ & $1.6(5.3 \mathrm{y})$ \\
\hline$[21]$ & Hurbanovo & Czech Rep. & $\begin{array}{c}\text { Urban, } \\
41 \mathrm{mg} /\left(\mathrm{m}^{2} \mathrm{~d}\right) \text { of } \mathrm{SO}_{2}\end{array}$ & $\mathrm{C} 2-\mathrm{C} 3$ & $\approx 3$ & $2(5-10 y)$ & $2-3(5-10 y)$ \\
\hline$[21]$ & Praha & Czech Rep. & $\begin{array}{c}\text { Urban, } \\
86 \mathrm{mg} /\left(\mathrm{m}^{2} \mathrm{~d}\right) \text { of } \mathrm{SO}_{2}\end{array}$ & C3 & $\approx 3$ & $3(5-10 y)$ & $3-4(5-10 y)$ \\
\hline$[22]$ & $\begin{array}{l}\text { Nat. Tsing-Hua } \\
\text { Univ. } \\
\end{array}$ & China & $\begin{array}{c}\text { Urban, } \\
60 \mathrm{mg} /\left(\mathrm{m}^{2} \mathrm{~d}\right) \text { of } \mathrm{SO}_{2} \\
\end{array}$ & C3 & $\approx 5$ & $22(5 y)$ & $1.5(5 y)$ \\
\hline$[21]$ & Kopisty & Czech Rep. & $\begin{array}{c}\text { Industrial, } \\
129 \mathrm{mg} /\left(\mathrm{m}^{2} \mathrm{~d}\right) \text { of } \\
\mathrm{SO}_{2}\end{array}$ & $\mathrm{C} 4$ & $5-10$ & $23(5 y)$ & $2(5 y)$ \\
\hline$[22]$ & China Steel Corp. & China & $\begin{array}{c}\text { Industrial, } \\
87 \mathrm{mg} /\left(\mathrm{m}^{2} \mathrm{~d}\right) \text { of } \mathrm{SO}_{2}\end{array}$ & C3 & $\approx 3$ & 11.7 (6 y) & $3(6 y)$ \\
\hline [23] & Amagasaki & Japan & $\begin{array}{c}\text { Industrial, } \\
152 \mathrm{mg} /\left(\mathrm{m}^{2} \mathrm{~d}\right) \text { of } \\
\mathrm{SO}_{2}\end{array}$ & C3 & $5-10$ & $10.2-14.6(5-7 y)$ & $\begin{array}{l}2.4-3.7 \\
(5-7 y)\end{array}$ \\
\hline$[23]$ & Kitakyushu & Japan & $\begin{array}{c}\text { Industrial, } \\
172 \mathrm{mg} /\left(\mathrm{m}^{2} \mathrm{~d}\right) \text { of } \\
\mathrm{SO}_{2}\end{array}$ & C3 & $5-10$ & $13.2(5 y)$ & $2.7(5 \mathrm{y})$ \\
\hline$[17]$ & Kearny (1940) & USA & Industrial & C3 & $5-10$ & $2.8(20 y)$ & $5.9(20 y)$ \\
\hline$[19]$ & Kearny (1970) & USA & Industrial & C3 & - & $1.5(8-16 y)$ & $2.1(8-16 y)$ \\
\hline$[24]$ & Newark & USA & Industrial & $\mathrm{C} 3-\mathrm{C} 4$ & 3 & $10.3(7 \mathrm{y})$ & $1.9(7 \mathrm{y})$ \\
\hline$[24]$ & Whiting & USA & Industrial & $\mathrm{C} 3-\mathrm{C} 4$ & 3 & $10.3(7 y)$ & $1.8(7 \mathrm{y})$ \\
\hline$[25]$ & Rankin & USA & Industrial & C3 & $\approx 8$ & $4.20(17 y)$ & - \\
\hline$[25]$ & Rankin & USA & Industrial & $\mathrm{C} 3$ & $5-10$ & $7.74(10 y)$ & $4.31(10 y)$ \\
\hline$[25]$ & Columbus & USA & Industrial & C3 & $5-10$ & $7.72(10 y)$ & $2.28(10 y)$ \\
\hline$[25]$ & Bethlehem & USA & Industrial & C3 & 5 & $6.54(10 y)$ & $3.13(10 y)$ \\
\hline$[17]$ & Kure Beach $(250 \mathrm{~m})$ & USA & $\begin{array}{c}\text { Marine, } \\
91 \mathrm{mg} /\left(\mathrm{m}^{2} \mathrm{~d}\right) \text { of } \mathrm{Cl}^{-}\end{array}$ & $\mathrm{C} 2-\mathrm{C} 3$ & $>10$ & $3.5(15.5 y)$ & $2.3(15.5 y)$ \\
\hline$[26]$ & Kure Beach $(250 \mathrm{~m})$ & USA & $\begin{array}{c}\text { Marine, } \\
91 \mathrm{mg} /\left(\mathrm{m}^{2} \mathrm{~d}\right) \text { of } \mathrm{Cl}^{-}\end{array}$ & $\mathrm{C} 2-\mathrm{C} 3$ & $>15$ & $7.5(16 y)$ & - \\
\hline$[24]$ & Kure Beach $(25 \mathrm{~m})$ & USA & $\begin{array}{c}\text { Marine, } \\
485 \mathrm{mg} /\left(\mathrm{m}^{2} \mathrm{~d}\right) \text { of } \\
\mathrm{Cl}^{-}\end{array}$ & C3 & 7 & $14.6(7 y)$ & $5.7(7 \mathrm{y})$ \\
\hline$[24]$ & Point Reyes & USA & Marine & $\mathrm{C} 4$ & 7 & $18.0(7 y)$ & $3.3(7 y)$ \\
\hline [27] & Miraflores & Panama & Marine & C3 & $>15$ & $6.8(16 y)$ & $2.7(16 y)$ \\
\hline [27] & Limon Bay & Panama & Marine & C3 & $>15$ & $12.7(16 y)$ & $2.0(16 y)$ \\
\hline [13] & Block Island & USA & Marine & $\mathrm{C} 2-\mathrm{C} 3$ & $>17$ & $12.7(17.1 \mathrm{y})$ & 一 \\
\hline
\end{tabular}

$R^{*}$ : ratio between carbon steel (CS) corrosion and weathering steel (WS) corrosion.

-: not available. 
$\left[\mathrm{Cu}_{4}\left(\mathrm{SO}_{4}\right)(\mathrm{OH})_{6}\right]$ or $\left[\mathrm{Cu}_{3}\left(\mathrm{SO}_{4}\right)(\mathrm{OH})_{4}\right]$. These compounds can precipitate in pores of the rust layer, thereby improving the barrier effect of the patina [28].

Studies into the effect of $\mathrm{SO}_{2}$ pollution in the atmosphere on WS corrosion are very scarce. Perhaps the most important information in this respect is that obtained in an 8-year study performed at numerous locations within the framework of the UNECE International Cooperative Programme on effects on materials, including Historic and Cultural monuments [30]. Figure 1 plots the WS corrosion rate after 8 years of exposure versus the $\mathrm{SO}_{2}$ concentration in the atmosphere, and a clear effect of $\mathrm{SO}_{2}$ in the atmospheric corrosion of WS is observed. According to Leygraf and Gradael, it seems that a certain amount of deposited $\mathrm{SO}_{2}$ is beneficial. However, large amounts result in intense acidification of the aqueous layer, triggering dissolution and hindering precipitation [28].

With regard to marine atmospheres, although little information is available (see Table 2), corrosion rates are seen to be higher and the time taken to reach the steady state, if it is reached, tends to be longer, in excess of 15 years as it was mentioned previously. The action of chloride ions in this type of atmosphere seems to hinder the formation of protective rust layers, thus impeding the use of conventional WS.

Another aspect about which bibliographic information is highly variable is the relationship between mild steel corrosion rate and WS corrosion rate for different exposure times and atmosphere types. It is common to find general statements in the literature such as: "WS has to 4,5 to 8,10 , and so forth, times more corrosion resistance than carbon steel," or "in comparison to carbon steels, WS may have corrosion rates of more than one order of magnitude less, depending on the environmental conditions." That relationship obviously depends again on the environmental conditions where both materials are exposed and the time of exposure. For this reason, the last column in Table 2 shows the relationship $R$ between carbon steel (CS) corrosion and conventional WS corrosion for the longest exposure time in each of the atmospheres for which information is available in the reviewed literature. The average values yield relationships of 2.3 (rural-urban atmospheres), 2.9 (industrial atmospheres), and 3.2 (marine atmosphere). The lack of precision is great, and a certain tendency is seen for the value of this relationship to rise with time, which means that the beneficial effects of WS are increasing. It is also noted that the reduction in WS corrosion seems to be greater in the most aggressive atmospheres (industrial or marine).

\section{Morphology of the Protective Rust Layer}

The formation of the protective rust layer on weathering steels is not yet completely understood. In the late 1960s, researchers suggested that the stratification of rust layers was an intrinsic property of protective rusts formed on WS. The work of Okada [31] is perhaps the most commonly cited in this respect, where the authors show that unlike carbon steel, upon which only one stratum of rust is formed, on WS, two strata of rust may be observed after a certain exposure time, consisting of an internal layer with protective characteristics and an unprotective outer layer. Similarly, Leygragh and

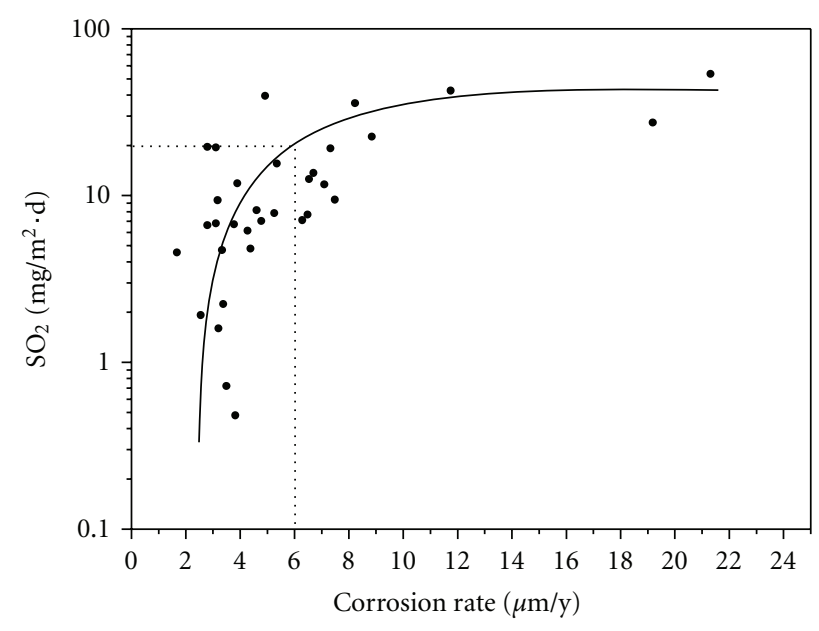

FIGURE 1: Variation of atmospheric corrosion rate for conventional weathering steel with $\mathrm{SO}_{2}$ content in the atmosphere, constructed from date provided by UNECE, after 8 years of exposure.

Gradael [28] and Zhang et al. [9] state that the structure of rust on WS is different from that on iron or carbon steels. It is characterised by a double-layer structure, with the inner phase providing a greater barrier to oxygen and water than the outer phase. The outer phase is flaky and poorly adherent, whereas the inner phase adheres well.

Microscopic observation performed by Yamashita et al. [32] and Okada [31] found that the rust layer can be divided into two layers: one corresponds to the outer layer which is optically active, and the other is the inner layer which is optically isotropic (darkened). On the other hand, the surface rust formed on the mild steel consists of the mottled structure consisting of the optically active and isotropic corrosion products. The optically isotropic layer was mainly composed of amorphous spinel-type iron oxide and the optically active layer was $\gamma$-FeOOH. Raman et al. [33] and Suzuki et al. [34] described that the outer layer of WS contains several different crystalline oxyhydroxides, including lepidocrocite $(\gamma-\mathrm{FeOOH})$, goethite $(\alpha-\mathrm{FeOOH})$, akaganeite $(\beta$-FeOOH $)$, feroxyhyte $(\delta$-FeOOH $)$, maghemite $\left(\gamma-\mathrm{Fe}_{2} \mathrm{O}_{3}\right)$, magnetite $\left(\mathrm{Fe}_{3} \mathrm{O}_{4}\right)$, and ferrihydrite $\left(\mathrm{Fe}_{5} \mathrm{HO}_{8} \cdot 4 \mathrm{H}_{2} \mathrm{O}\right)$, and an inner region, consisting primarily of dense amorphous $\mathrm{FeOOH}$ with some crystalline $\mathrm{Fe}_{3} \mathrm{O}_{4}$ (Figure 2).

Dillmann et al. [35] studied in detail that the major phases of the rust layers are magnetite, goethite, and lepidocrocite. Lepidocrocite seems to be more present in the outer layer and goethite seems to be the major constituent of the inner layer. Furthermore, Zhang et al. [9] pointed out that the inner rust layer is enriched in some kind of alloying elements just like $\mathrm{Cr}, \mathrm{Cu}$, and other elements, whereas the outer layer, which is distributed with cracks and pores, could not inhibit the entrance of the corrosive electrolyte.

Now it is generally agreed that both CS and WS form rusts that tend to stratify with exposure time [36]. Both common carbon steels and WS present a rust layer that is in turn composed of two sublayers, a reddish outer layer and a dark grey inner layer (polarised light). This stratification is independent of the degree of protection afforded by the rust. 


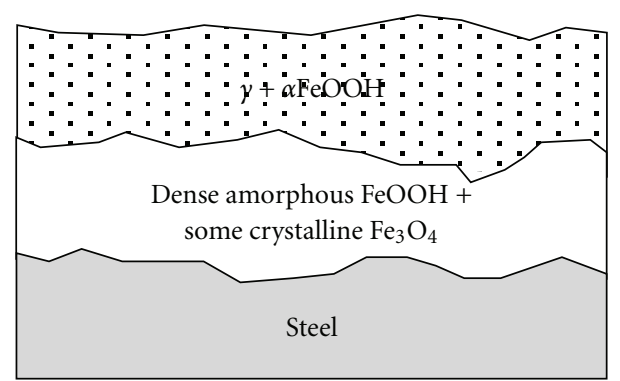

FIgure 2: Dual nature of the rust layer.

The composition and morphology of the protective patina formed on WS is very different to the coating formed on carbon steel. The difference between the rust layers formed on carbon steel and on WS is that the $\alpha$-phase (goethite phase) on the latter forms a densely packed and uniform layer of nanometre-sized particles, which are closely attached to the underlying steel substrate. On carbon steel, however, the distribution of phases is more heterogeneous, resulting in a rust layer with a mottled structure. The corrosion protection ability of WS is mainly attributed to this dense $\alpha$-phase whose formation is stimulated by dry-wet-dry cycling [3].

According to Yamashita and Uchida [37], the protective rust layer on WS is usually formed spontaneously after a certain number of years of exposure. Until the protective ability of the rust layer emerges, the WS corrosion rate is not especially low. Furthermore, the protective rust layer cannot form in coastal environments where the amount of airborne sea-salt particles is relatively high. The higher the chloride deposition rate in marine atmospheres, the greater the degree of flaking observed, with loosely adherent flaky rust favouring rust film breakdown (detachment, spalling) and the initiation of fresh attack. The morphologic characteristics of the protective patina will therefore depend on the type of environment (rural, urban, industrial, or marine), WS composition, years of exposure, relative humidity, temperature, and pollutants $\left(\mathrm{SO}_{2}, \mathrm{Cl}^{-}\right.$, etc. $)$as the main factors governing the formation and transformation of the protective layer.

\section{Allowable Corrosion Rate for Unpainted Weathering Steel}

In 1962, Larrabe and Coburn [17] suggested that an average WS corrosion loss of $2-3$ mils $(25-75 \mu \mathrm{m})$ in 15 years in a given atmosphere (i.e., 1.7-5 $\mu \mathrm{m} / \mathrm{y}$ ) would be sufficiently low for this steel to be used in the atmosphere without being painted.

In Japan, conventional WS specified as Japan Industrial Standard G 3114 SMA (JIS-SMA Weathering Steel), which is almost the same as that first commercialised by US Steel Corporation in the 1930s, can be used for bridges in environments where less than $0.3 \mathrm{~mm}$ corrosion loss per side is expected in 50 years of exposure, that is, $6 \mu \mathrm{m} / \mathrm{y}$ [38]. It is important to note that 50 years does not mean bridge lifetime and that $0.3 \mathrm{~mm}$ of corrosion loss does not define the criteria of structural stability. These values are used to define the corrosivity of the atmosphere, and in general steel structures can be said to be sufficiently durable to accommodate a great deal of corrosion before any risk of collapse. Conventional WS is currently considered in Japan to be appropriate for bridges in environments where corrosion loss on one side of a girder is less than $0.5 \mathrm{~mm}$ in 100 years of exposure, that is, $5 \mu \mathrm{m} / \mathrm{y}$ [39].

In USA, according to Cook [40], the acceptable corrosion rate for weathering steel in medium corrosivity locations is $120 \mu \mathrm{m}$ maximum for 20 years of exposure, that is, $6 \mu \mathrm{m} / \mathrm{y}$ again. Due to the development of rust patina during the lifetime of a structure that incorporates unpainted WS, a corrosion allowance should be made on each exposed surface, representing a loss of thickness of the material used for structural purposes [41]:

(i) for atmospheric conditions defined by ISO 9223 [12] as class C1, C2, or C3 ("mild" environments for WS), the corrosion allowance should be $1 \mathrm{~mm}$ per surface, while for class C4 on C5 ("Severe" environments for WS), the corrosion allowance shall be $1.5 \mathrm{~mm}$ per surface,

(ii) for the "interior" surface of box sections, the allowance shall be $0.5 \mathrm{~mm}$.

Following the same criterion as Japan and USA for the use of unpainted WS allowing a maximum atmospheric corrosion rate for steel of $6 \mu \mathrm{m} / \mathrm{y}$ in long-term exposures, the seventh column in Table 2 presents information on this aspect. According to the information contained in Table 2, conventional WS may be used in rural and urban areas without excessive $\mathrm{SO}_{2}$ pollution where the WS corrosion rate at the end of the exposure period is usually less than $6 \mu \mathrm{m} / \mathrm{y}$; however, it should not be used in industrial or marine atmospheres because long-term WS corrosion rate has higher values, usually in excess of $6 \mu \mathrm{m} / \mathrm{y}$. It should nevertheless be noted that the available information corresponds to relatively short exposure times in which, as has been commented above, WS still presents high corrosion rates and where protective rust layers have not perhaps yet had time to form.

\section{Guideline Levels for Environmental Parameters (TOW, $\mathrm{SO}_{2}$, and $\mathrm{Cl}^{-}$) for the Use of Conventional Weathering Steel}

6.1. Japan. An application guideline for unpainted WS has been prepared based on the results of surveys and examinations, including the long-term exposure tests carried out from 1981 to 1993 by three organisations: the Public Works Research Institute of the Construction Ministry, the Japan Association of Steel Bridge Construction, and the Kozai Club [38]. Figure 3 shows the relationship between atmospheric salinity and WS corrosion (per exposed surface), differentiating between two zones according to the adherent or nonadherent nature of the rust formed. Salinity measurements were obtained by the gauze method (JIS-Z2381) [42]. Bearing in mind the maximum corrosion rate permitted for the use of WS, $6 \mu \mathrm{m} / \mathrm{y}$, an $\mathrm{NaCl}$ critical level of $0.05 \mathrm{mg} /\left(\mathrm{dm}^{2} \mathrm{~d}\right)$ or $3 \mathrm{mg} /\left(\mathrm{m}^{2} \mathrm{~d}\right)$ of $\mathrm{Cl}^{-}$is established for 


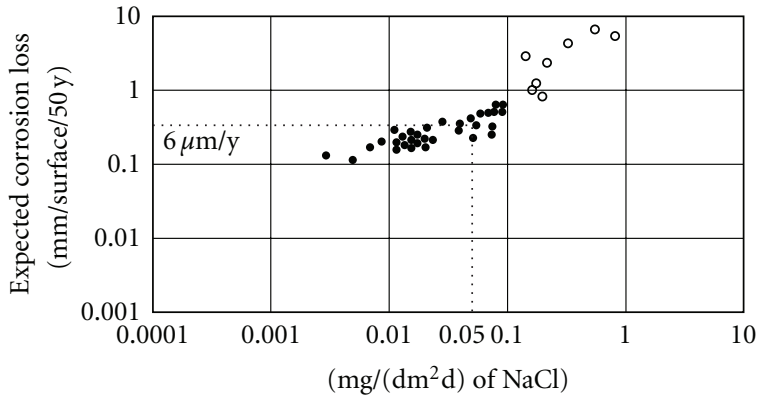

- Adherent

- Not adherent

FIGURE 3: Influence of air-born salts (atmospheric salinity) on the stability of the protective layer of corrosion products formed on WS.

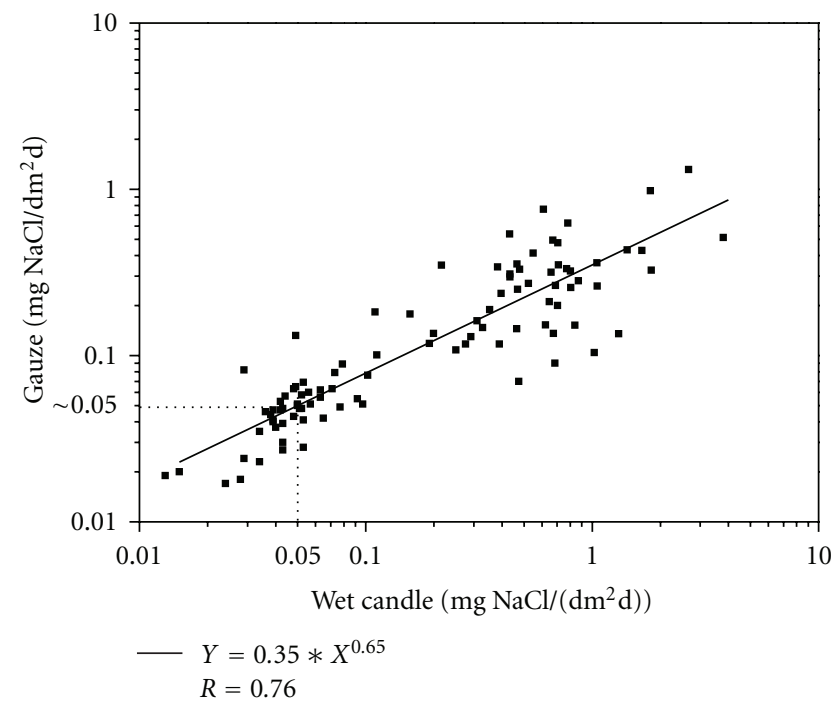

FIGURE 4: Relationship between measurements obtained by the wet candle method and the gauze method.

airborne salt [43]. At the present time the $\mathrm{NaCl}$ limit is set at $0.1 \mathrm{mg} /\left(\mathrm{dm}^{2} \mathrm{~d}\right)$ or $6 \mathrm{mg} /\left(\mathrm{m}^{2} \mathrm{~d}\right)$ of $\mathrm{Cl}^{-}$and there is even talks of a range of $0.1-0.2 \mathrm{mg} /\left(\mathrm{dm}^{2} \mathrm{~d}\right)$ of $\mathrm{NaCl}$ or $6-12 \mathrm{mg} /\left(\mathrm{m}^{2} \mathrm{~d}\right)$ of $\mathrm{Cl}^{-}$, depending on the conditions of usage [44].

6.2. United Kingdom. The United Kingdom Department of Transport Standard BD 7 [41], "Use of WS for highway structures," suggested in 1981 that uncoated WS should not be used when:

(1) the chloride level exceeds $0.1 \mathrm{mg} /\left(\mathrm{dm}^{2} \mathrm{~d}\right)$ or $10 \mathrm{mg} /\left(\mathrm{m}^{2} \mathrm{~d}\right)$,

(2) the yearly average time of wetness exceeds $60 \%$,

(3) the threshold level for sulphur trioxide exceeds $2.1 \mathrm{mg} /\left(\mathrm{dm}^{2} \mathrm{~d}\right)$ or $168 \mathrm{mg} /\left(\mathrm{m}^{2} \mathrm{~d}\right)$ of $\mathrm{SO}_{2}$.

The 2001 edition of BD 7 established new critical levels for $\mathrm{Cl}^{-}$and $\mathrm{SO}_{2}$. A salinity classification of $\mathrm{S} 3\left(\geq 300 \mathrm{mg} /\left(\mathrm{m}^{2} \mathrm{~d}\right)\right.$ of $\left.\mathrm{Cl}^{-}\right)$and $\mathrm{SO}_{2}$ levels above P3 $\left(\geq 200 \mathrm{mg} /\left(\mathrm{m}^{2} \mathrm{~d}\right)\right)$ should be avoided for use of uncoated WS.
6.3. USA. According to United States government guidelines [45], the following conditions should be avoided if WS is used: Chloride deposition $>50 \mathrm{mg} /\left(\mathrm{m}^{2} \mathrm{~d}\right)$, sulphur dioxide deposition $>168 \mathrm{mg} /\left(\mathrm{m}^{2} \mathrm{~d}\right)$, as United Kingdom (Standard BD $7[41]$ ), and average time of wetness $>60 \%$. The time of wetness is here defined as the time during which the relative humidity is $>80 \%$ and the temperature is $>0{ }^{\circ} \mathrm{C}$. Environmental data has been obtained in accordance with ISO 9223 [12]. Unlike in Japan, atmospheric salinity data has been obtained by the wet candle method (ISO 9223) [12]. The relationship between the data obtained with these two techniques, the gauze method and the wet candle method [46], is displayed in Figure 4 for $\mathrm{NaCl}$ levels between $0.013 \mathrm{y}$ $3.8 \mathrm{mg} /\left(\mathrm{dm}^{2} \mathrm{~d}\right)$, obtained by the wet candle method [47].

It shows that the wet candle method is more sensitive to the presence of $\mathrm{NaCl}$, capturing greater amount of aerosol that the gauze method for $\mathrm{NaCl}$ levels higher than $0.05 \mathrm{mg} /\left(\mathrm{dm}^{2} \mathrm{~d}\right)$.

Unlike the effect of atmospheric salinity on WS corrosion, for which valuable information was obtained in 12-year exposure tests carried out to classify the severity of environments in Japan (Figure 3), no similar study concerning the effect of atmospheric $\mathrm{SO}_{2}$ has been found in the literature. Nevertheless, the graph in Figure 1 draws on interesting results obtained by UNECE [30] for the case of weathering steel exposed for 8 years in numerous atmospheres in Europe and America. The graph excludes sites where the atmospheric salinity or time of wetness is excessively high for protective rust layers to form $(\geq 6 \mathrm{mg} / \mathrm{L}$ of $\mathrm{Cl}^{-}$in rain water and TOW in excess of $\left.5500 \mathrm{~h} / \mathrm{y}\right)$. This graph allows a critical level of around $20 \mathrm{mg} /\left(\mathrm{m}^{2} \mathrm{~d}\right)$ of $\mathrm{SO}_{2}$ to be established, in accordance with the criterion for the use of unpainted WS in atmospheric exposure $(6 \mu \mathrm{m} / \mathrm{y})$.

In another study performed in the former Czechoslovakia by Knotkova et al. at different testing sites with high$\mathrm{SO}_{2}$ pollution, an $\mathrm{SO}_{2}$ critical level of $90 \mathrm{mg} /\left(\mathrm{m}^{2} \mathrm{~d}\right)$ was established for the use of WS in this type of atmospheres [21], much higher than the obtained level from Figure 1.

\section{Conclusions}

From the bibliographic review performed, the following conclusions may be drawn.

(i) Although the power function $\left(C=A t^{n}\right)$ seems to provide a good fit of the evolution of atmospheric corrosion of weathering steels with exposure time, the power-linear model provides better predictions for long-term exposure times.

(ii) The time taken for the rust layer to stabilise obviously depends on the environmental conditions of exposure: 3-5 years for rural or urban atmospheres; 5-10 years for industrial atmospheres; >15 years for marine atmospheres, if a steady state is ever actually reached in this type of atmosphere. Atmospheres polluted with $\mathrm{SO}_{2}$, if not strongly polluted ( $>90 \mathrm{mg} /\left(\mathrm{m}^{2} \mathrm{~d}\right.$ ) of $\left.\mathrm{SO}_{2}\right)$, promote earlier stabilisation of the rust layers, $(\approx 3$ years $)$ possibly due to the 
sealing of internal porosity in the rust by corrosion products formed between $\mathrm{SO}_{2}$ and copper in the WS.

(iii) With regard to the morphology of the rust layers formed in the atmosphere, two sublayers are formed on both carbon steel and WS, the innermost being responsible for the protective properties of the rust in the case of WS.

(iv) There seems to be general agreement on the allowable corrosion rate $(6 \mu \mathrm{m} / \mathrm{y})$ for the use of unpainted WS in the atmosphere.

(v) There is a lack of unified criteria on guideline environmental conditions $\left(\mathrm{SO}_{2}, \mathrm{Cl}^{-}\right)$for the use of unpainted WS. The chloride level allowed in Japan seems to be excessively low $\left(6 \mathrm{mg} /\left(\mathrm{m}^{2} \mathrm{~d}\right)\right)$ and excessively high $\left(\geq 300 \mathrm{mg} /\left(\mathrm{m}^{2} \mathrm{~d}\right)\right)$ in United Kingdom, while the $\mathrm{SO}_{2}$ levels allowed in the United Kingdom and USA seem excessively high (200 and $\left.168 \mathrm{mg} /\left(\mathrm{m}^{2} \mathrm{~d}\right)\right)$, respectively.

\section{References}

[1] T. Murata, "Weathering steel," in Uhlig's Corrosion Handbook, R. W. Revie, Ed., J. Wiley \& Sons, New York, NY, USA, 2000.

[2] I. Kage, K. Matsui, and F. Kawabata, "Minimum maintenance steel plates and their application technologies for bridgelife cycle cost reduction technologies with environmental safeguards for preserving social infrastructure assets," JFE Technical Report, no. 5, pp. 37-44, 2005.

[3] D. C. Cook, "Spectroscopic identification of protective and non-protective corrosion coatings on steel structures in marine environments," Corrosion Science, vol. 47, no. 10, pp. 2550-2570, 2005.

[4] K. Bohnenkamp, G. Burgmann, and W. Schwenk, "Investigations of the atmospheric corrosion of plain carbon and low alloy steels in industrial, rural and sea air," Stahl und Eisen, vol. 93, no. 22, pp. 1054-1060, 1973.

[5] R. A. Legault and A. G. Preban, "Kinetics of the atmospheric corrosion of low-alloy steels in an industrial environment," Corrosion, vol. 31, no. 4, pp. 117-122, 1975.

[6] M. Pourbaix, "The linear bilogarithmic law for atmospheric corrosion," in Atmospheric Corrosion, W. H. Ailor, Ed., J. Wiley \& Sons, New York, NY, USA, 1982.

[7] S. Feliu and M. Morcillo, "Atmospheric corrosion testing in spain," in Atmospheric Corrosion, W. H. Ailor, Ed., pp. 913922, J. Wiley \& Sons, New York, NY, USA, 1982.

[8] R. A. Legault and V. P. Pearson, "Atmospheric Corrosion in Marine Environments," National Association of Corrosion Engineers, vol. 34, no. 12, pp. 433-437, 1978.

[9] Q. C. Zhang, J. S. Wu, J. J. Wang, W. L. Zheng, J. G. Chen, and A. B. Li, "Corrosion behavior of weathering steel in marine atmosphere," Materials Chemistry and Physics, vol. 77, no. 2, pp. 603-608, 2003.

[10] R. H. McCuen, P. Albrecht, and J. G. Cheng, "A New approach to power-model regression of corrosion penetration data," in Corrosion Form and control for Infrastructure, V. Chaker, Ed., ASTM STP 1137, American Society for Testing and Materials, Philadelphia, Pa, USA, 1992.

[11] ISO 9224, Corrosion of Metals and Alloys-Corrosivity of Atmospheres-Guiding Values for the Corrosivity Categories, Geneve, Switzerland, 1992.
[12] ISO 9223, Corrosion of Metals and Alloys-Corrosivity of Atmospheres-Classification, Geneve, Switzerland, 1992.

[13] R. H. McCuen and P. Albrecht, "Composite modeling of atmospheric corrosion penetration data," in Application of Accelerated Corrosion Test to Service Life Prediction of Materials, G. Cragnolino and N. Sriddhar, Eds., ASTM STP 1194, ASTM, Philadelphia, Pa, USA, 1994.

[14] D. E. Klinesmith, R. H. McCuen, and P. Albrecht, "Effect of environmental conditions on corrosion rates," Journal of Materials in Civil Engineering, vol. 19, no. 2, pp. 121-129, 2007.

[15] H. E. Townsend, "Effects of alloying elements on the corrosion of steel in industrial atmospheres," Corrosion, vol. 57, no. 6, pp. 497-501, 2001.

[16] S. W. Dean, D. Knotkova, and K. Kresilova, ISOCORRAG International Atmospheric Exposure Program: Summary of Results ASTM Data Series 71, ASTM International, West Conshohorken, Pa, USA, 2010.

[17] C. P. Larrabe and S. K. Coburn, Proceedings of the 5th International Congress on Metal Corrosion, London, UK, 1962.

[18] H. E. Townsend and J. C. Zoccola, "Eight-year atmospheric corrosion performance of weathering steel in industrial, rural and marine environments," in Atmospheric Corrosion, S. W. Dean Jr. and E. C. Rhea, Eds., ASTM STP 767, ASTM, Philadelphia, Pa, USA, 1982.

[19] S. K. Coburn, M. E. Komp, and S. C. Lore, Atmospheric Corrosion, ASTM STP 1239, ASTM, Philadelphia, Pa, USA, 1995.

[20] F. H. Haynie and J. B. Upham, "Effects of atmospheric pollutans on corrosion behavior of steels," Material Performance, vol. 10, no. 11, pp. 18-21, 1971.

[21] D. Knotkova, J. Vlckova, and J. Honzak, "Atmospheric corrosion of weathering steels," in Atmospheric Corrosion, S. W. Dean Jr. and E. C. Rhea, Eds., ASTM STP 767, ASTM, Philadelphia, Pa, USA, 1982.

[22] J. H. Wang, F. I. Wei, Y. S. Chang, and H. C. Shih, "The corrosion mechanisms of carbon steel and weathering steel in $\mathrm{SO}_{2}$ polluted atmospheres," Materials Chemistry and Physics, vol. 47, no. 1, pp. 1-8, 1997.

[23] T. Moroishi and J. Satake, "Effect of alloying elements on atmospheric corrosion of high tensile strength steels," Journal of the Iron and Steel Institute of Japan, vol. 59, no. 2, pp. 293300, 1973.

[24] G. B. Mannweiler, Corrosion Test Results on Fifteen Ferrous Metals After Seven-Year Atmospheric Exposure, ASTM STP 435, ASTM, Philadelphia, Pa, USA, 1968.

[25] B. J. Horton, The Composition, Structure and Growth of Atmospheric Rust on Various Steels, University Lehigh, 1964.

[26] H. R. Copson, "Long-time atmospheric corrosion test on lowalloy steels," Proceedings ASTM, vol. 60, 1960.

[27] C. R. Southwell, J. D. Bultman, and A. L. Alexander, "Corrosion of metals in tropical environments-final report of 16year exposures," Materials Performance, vol. 15, no. 7, pp. 926, 1976.

[28] C. Leygraf and T. Gradael, Atmospheric Corrosion, Electrochemical Society Series, J. Wiley \& Sons, New York, USA, 2000.

[29] J. Satake and T. Moroishi, Proceedings of the 5th International Congress on Metal Corrosion, NACE, Houston, Tex, USA, 1974.

[30] J. Tidblad, V. Kucera, and A. A. Mikhailov, UNECE International Cooperative Programme of Effects on Materials, Including Historic and Cultural Monuments, Report No. 30: Statistical Analysis of 8 Year Materials Exposure and Acceptable Deterioration and Pollution Levels. 
[31] H. Okada, Proceedings of the 4th International Congress on Metal Corrosion, NACE, Houston, Tex, USA, 1972.

[32] M. Yamashita, H. Miyuki, Y. Matsuda, H. Nagano, and T. Misawa, "The long term growth of the protective rust layer formed on weathering steel by atmospheric corrosion during a quarter of a century," Corrosion Science, vol. 36, no. 2, pp. 283-299, 1994.

[33] A. Raman, S. Nasrazadani, and L. Sharma, "Morphology of rust phases formed on weathering steels in various laboratory corrosion tests," Metallography, vol. 22, no. 1, pp. 79-96, 1989.

[34] I. Suzuki, Y. Hisamatsu, and N. Masuko, "Nature of atmospheric rust on iron," Journal of the Electrochemical Society, vol. 127, no. 10, pp. 2210-2215, 1980.

[35] P. Dillmann, F. Mazaudier, and S. Hoerlé, "Advances in understanding atmospheric corrosion of iron: I. Rust characterisation of ancient ferrous artefacts exposed to indoor atmospheric corrosion," Corrosion Science, vol. 46, no. 6, pp. 1401-1429, 2004.

[36] L. M. Ocampo, "Influência dos elementos de liga Na corrosão de aços patináveis," in Engenharia Metalúrgica e de Materiais, p. 145, Universidade Federal do Rio de Janeiro, Rio de Janeiro, Brazil, 2005.

[37] M. Yamashita and H. Uchida, "Recent research and development in solving atmospheric corrosion problems of steel industries in Japan," Hyperfine Interactions, vol. 139-140, no. 1-4, pp. 153-166, 2002.

[38] K. Club, Ed., "Guideline for desing and construccion of bridges by weathering steel," Tech. Rep., Tokio, Japan, 1993.

[39] "Specification for highway bridges," in Japan Road Association, Tokio, Japan, 2002.

[40] D. C. Cook, The Corrosion of High Performance Steel in Adverse Environments, ISIAME, 2004.

[41] BD7-01, Wetahering Steel for Highway Structures, vol. 2, section 3, part 8 of Desing Manual for Roads and Bridges, The United Kingdom Department of Transport, London, UK, 2001.

[42] Recommended Practice for Weathering Test, JIS-Z-2381, Japan Industrial Standard, 1987.

[43] M. Takabe, M. Ohya, and S. Ajiki, "Estimation of quantity of $\mathrm{Cl}^{-}$from deicing salts on weathering steels used for bridges," Steel Structures, vol. 8, pp. 73-81, 2008.

[44] S. S. Kim, "Appropriate environmental sphere of application for unpainted weathering steel," Journal of Industrial and Engineering Chemistry, vol. 9, no. 2, pp. 212-218, 2003.

[45] Technical Advisory 5140.22, Uncoated Weathering Steel in Structures, US Department of Transportation, Federal Highway Administration, 1989.

[46] Standard Test Method for Determining Atmospheric Chloride Deposition Rate by Wet Candle Method, ASTM G140-96, ASTM, Philadelphia, Pa, USA, 1996.

[47] S. W. Dean, "Atmospheric," in Corrosion test and Standards, Application and Interpretation, R. Baboian, Ed., pp. 116-125, ASTM, Philadelphia, Pa, USA, 1995. 

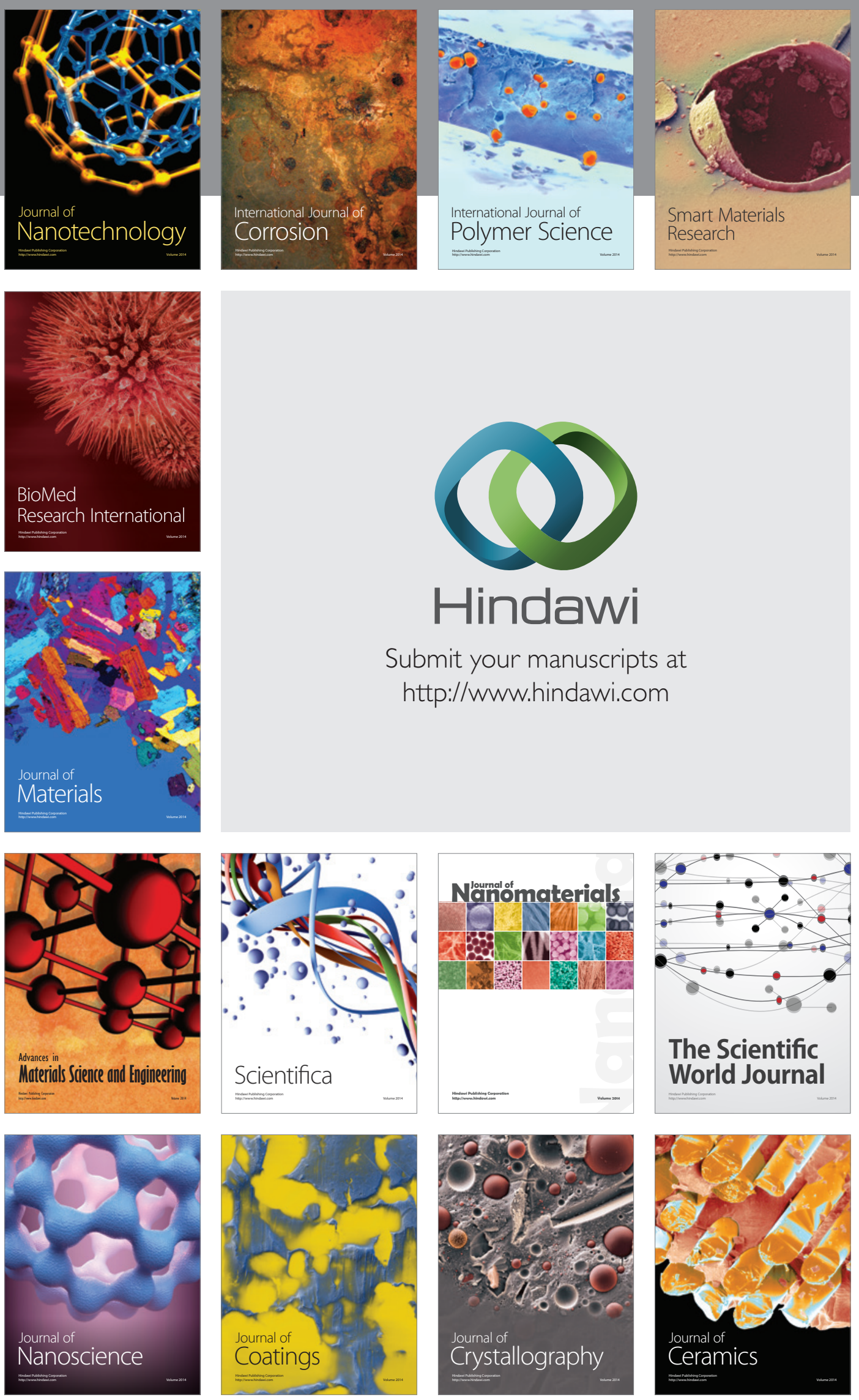

The Scientific World Journal

Submit your manuscripts at

http://www.hindawi.com

\section{World Journal}

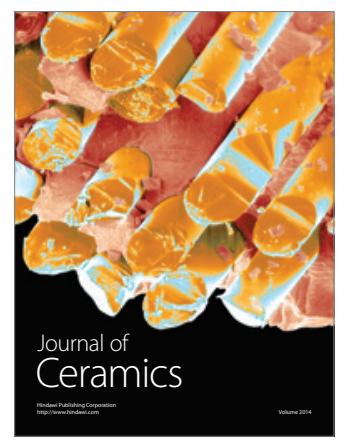

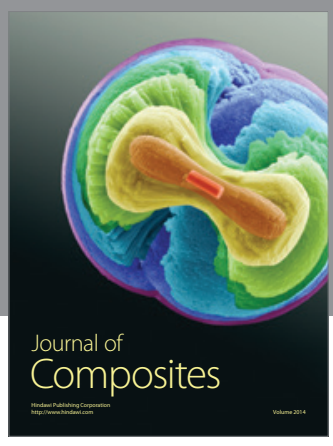
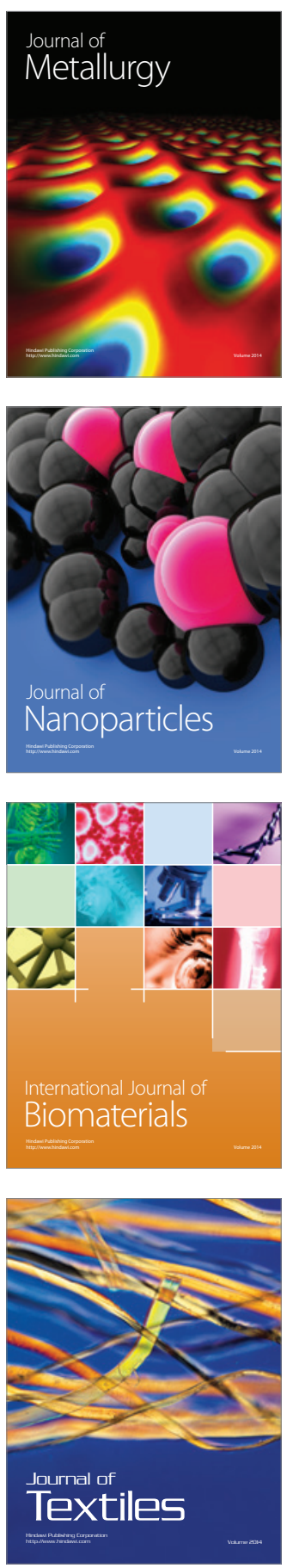